\title{
Geology of the Byrd Glacier Discontinuity (Ross Orogen): New survey data from the Britannia Range, Antarctica
}

\author{
R. Carosi, ${ }^{1}$ F. Giacomini, ${ }^{2}$ F. Talarico, ${ }^{2}$ and E. Stump ${ }^{3}$ \\ ${ }^{1}$ Università di Pisa, Dipartimento di Scienze della Terra, via S. Maria 53, 56126 Pisa, Italy ( carosi@dst.unipi.it ) \\ ${ }^{2}$ Università di Siena, Dipartimento di Scienze della Terra, via del Laterino 8, Siena, Italy ( giacomini@unisi.it ; talarico@unisi.it ) \\ ${ }^{3}$ School of Earth and Space Exploration, Arizona State University, Tempe, Arizona 85287, USA (ed.stump@asu.edu)
}

Abstract Field activities in the Britannia Range (Transantarctic Mountains, Antarctica) highlighted new geological features around the so-called Byrd Glacier discontinuity. Recent field surveys revealed the occurrence of significant amounts of medium- to high-grade metamorphic rocks, intruded by abundant coarse-grained porphyritic granitoids. Most of the granitoids are deformed, with foliation parallel to the regional foliation in the metamorphics. Two main episodes of deformation are observed. Tight to isoclinal folds and penetrative axial plane foliation are related to the D1 phase, open folds to the D2. The main foliation (D1) trends nearly E-W in agreement with the trend in the southern portion of the Byrd Glacier. In most outcrops, granitic dykes are folded and stretched by the D2 deformation, which shows similar characteristics with the D2 deformation south of the Byrd Glacier. This suggests the occurrence in the Ross orogen of an orogen-normal structure south and north of the Byrd Glacier.

Citation: Carosi, R., F. Giacomini, F. Talarico, and E. Stump, Geology of the Byrd Glacier Discontinuity (Ross Orogen): New survey data from the Britannia Range, Antarctica: in Antarctica: A Keystone in a Changing World-Online Proceedings of the $10^{\text {th }}$ ISAES, edited by A.K. Cooper and C.R. Raymond et al., USGS Open-File Report 2007-1047, Short Research Paper 030, 6 p.; doi:10.3133/of2007-1047.srp030

\section{Introduction}

The Ross orogen evolved during a Neoproterozoicearly Paleozoic cycle of deposition and orogenesis spanning the breakup of Rodinia and the consolidation of Gondwanaland (Hoffman, 1991; Moores, 1991; Dalziel, 1997). It is exposed throughout the $3,500 \mathrm{~km}$ length of the Transantarctic Mountains (TAM).

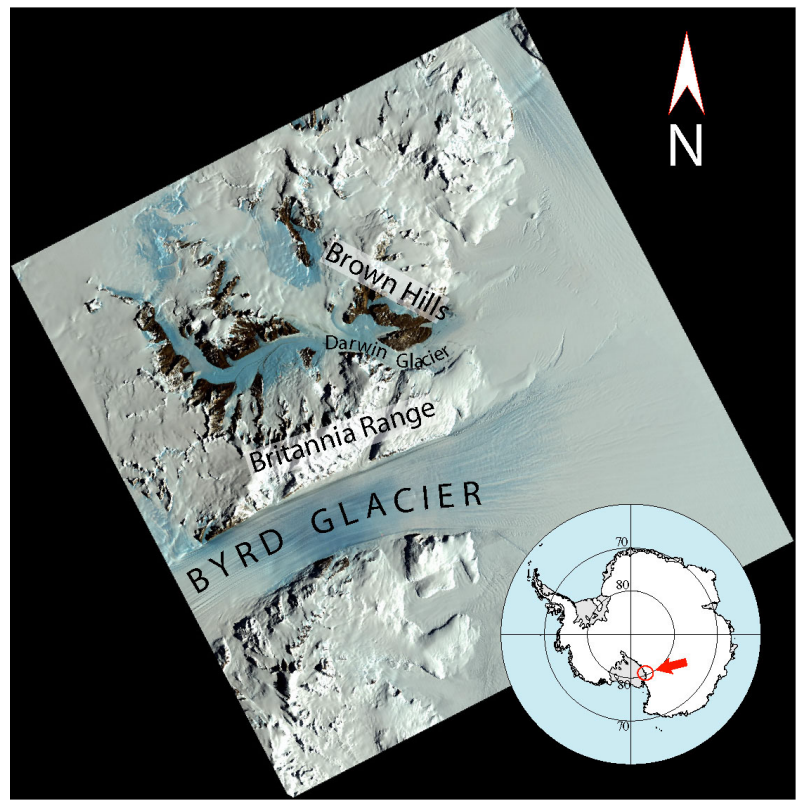

Figure 1. Satellite-image of the Byrd Glacier area and schematic map of Antarctica, with location of the study area.

Structural trends and the elongation of batholiths subparallel to the TAM, lead to the generally accepted model that the orogenic belt developed in response to a
Cambro-Ordovician subduction zone outboard of and parallel to the present day TAM (e.g. Goodge, 2002).

A striking exception to the structural and magmatic trends occurs in the Byrd Glacier. To the north the rocks are all plutonics and high-grade metamorphics ("Horney Formation" of Borg et al., 1989); to the south the rocks are primarily a Cambrian sequence (Byrd Group) of limestone, argillite, and conglomerate (Grindley 1963; Skinner 1964, Stump et al. 2004), with fold trends parallel to Byrd Glacier, approximately perpendicular to the trend throughout the TAM.

Stump et al. (2004) proposed a working hypothesis that the Byrd Glacier discontinuity represents a terrane boundary, with movement of a terrane ("Beardmore microcontinent" of Borg et al., 1990) from the SSE colliding with crust to the north of the Byrd Glacier.

Helicopter-supported field work, funded by the Italian Antarctic Programme (Project 4.2/2002), was carried out in austral season 2005/2006 in the Britannia Range (Fig. 1). The principal objectives of the project are summarised as follows:

i) investigate the largely unstudied and unmapped metamorphic and intrusive rock units in the Britannia Range and improve the understanding of the tectonic evolution of the Byrd Glacier region;

ii) compare different segments of the Ross Orogen in central TAM and Victoria Land;

iii) test the hypothesis that the Byrd Glacier marks a major terrane boundary.

\section{Geological setting}

Three main rock units are exposed in the Byrd Glacier area: the Byrd Group and the Selborne Group (Stump et al., 2004), cropping out south of Byrd Glacier, and the Horney Formation (Borg et al., 1989) extensively exposed north of the glacier in the Britannia Range. All three units are intruded by plutons referred 


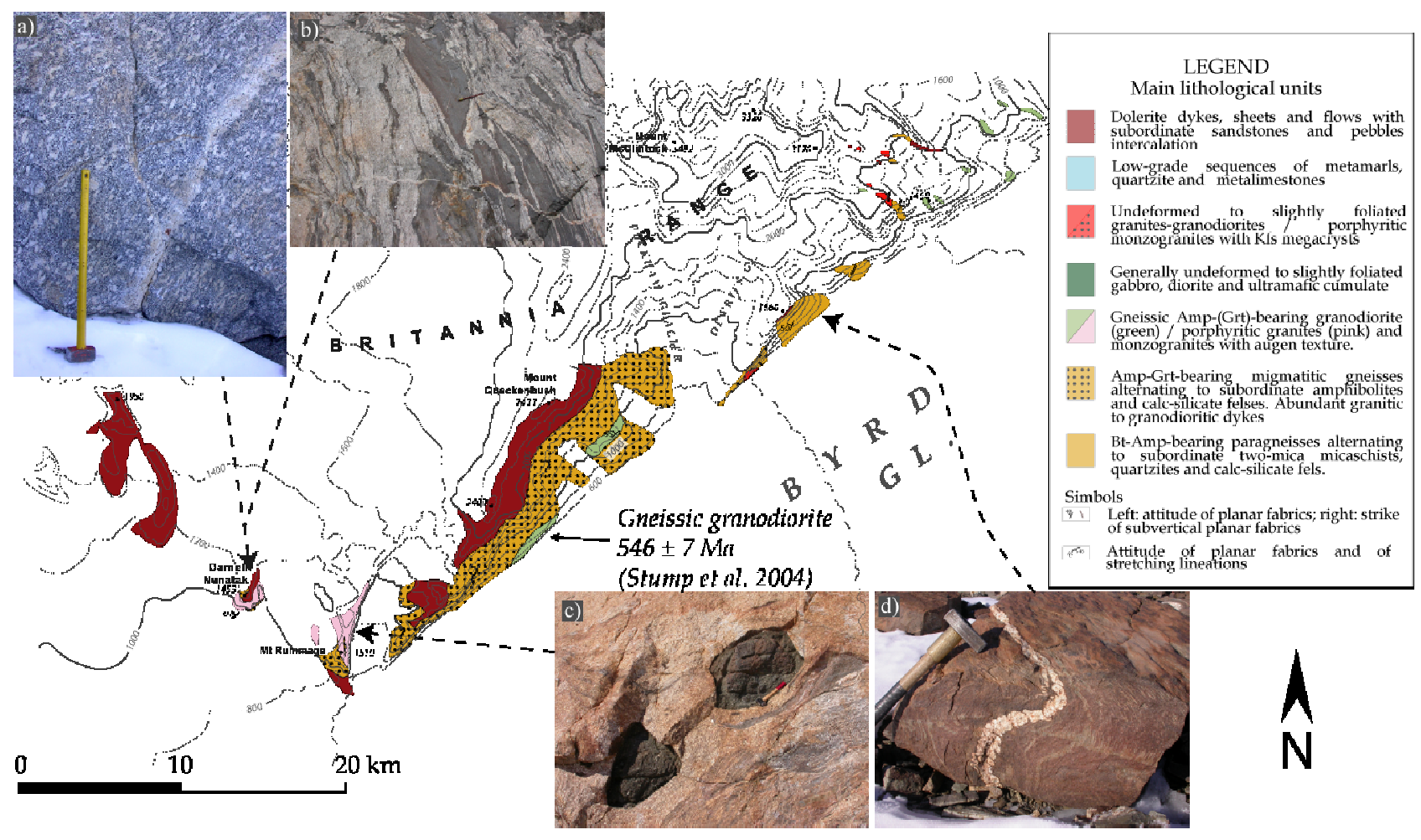

Figure 2. Geological map of the north side of the Byrd glacier and photographs of mesoscale outcrops. a) deformed granodiorite with relics of magmatic flow textures; b) migmatitic gneisses at the contact with the granodiorite; c) blobs of pyroxenite within a monzogranite intruding migmatitic gneisses; d) deformed quartz vein within mediumgrade Bt-Amp-bearing paragneisses.

to as the Granite Harbour Intrusives (Gunn and Warren, 1962), including monzo- and syenogranites, granodiorites and rare gabbros.

\section{The Byrd and Selborne Groups}

The Byrd and Selborne Groups are made up of anchimetamorphic to lower amphibolite-facies rocks, respectively. The Byrd group consists of the anchimetamorphic Lower Cambrian Shackleton Limestone and of the overlying Dick Formation and Douglas Conglomerate. Fossil content indicates a Lower Cambrian age, spanning from Adtabanian to Botomian, or possibly Toyonian (Hill, 1964). Recent geochronological data on tuffs and siliciclastic rocks confirm the deposition age to the Early Cambrian (Goodge et al. 2002; Stump et al., 2004).

Skinner (1964) designated the amphibolite-grade metamorphic rocks as the Selborne Marble. Stump et al. (2004) revised the stratigraphy to include Selborne Group made up of alternating marbles (Madison Marble) and pelitic schists (Contorsion Schist), which interfinger at their contact. The Selborne Group is characterized by two deformation phases which developed under lower amphibolite- and greenschistfacies conditions. Metaconglomerates and metabasalts also occur within the Selborne Group (Stump et al. 2004). The sequence is intruded by post-kinematic granitic plutons dated at $492 \pm 2 \mathrm{Ma}$ (Stump et al. 2002; 2006). Stump et al. (2004) correlated the Byrd Group with Selborne Group, Shackleton Limestone with Madison Marble and Starshot Formation and Douglas Conglomerate with Contortion Schist.

The Horney unit and associated Granite Harbour Intrusives north of Byrd Glacier

Plutonic and amphibolite-facies metamorphic rocks crop out to the north of Byrd Glacier in the Britannia Range for its full $75 \mathrm{~km}$ length and are known as "Horney Formation" (hereafter indicated as Horney unit), a "complexly folded amphibolite-grade banded gneisses and schists" (Borg et al., 1989).

Recent field data revealed the occurrence of medium- to high-grade metamorphic rocks (paragneisses, schists, calc-silicates and amphibolites) intruded by granitoids and rare mafic to ultramafic bodies. According to Stump et al. (2006) the evolution of the Horney Unit includes an early high-grade stage with generation of garnet- and amphibole-bearing leucosomes at minimum $\mathrm{T}$ of $650{ }^{\circ} \mathrm{C}$, followed by minor retrogression under lower grade conditions. Large bodies and dykes of coarse-grained deformed granitoids (mostly porphyritic granodiorites or monzogranites) are complexly interlayered with the metamorphic sequences. Their deformation is usually concordant with 


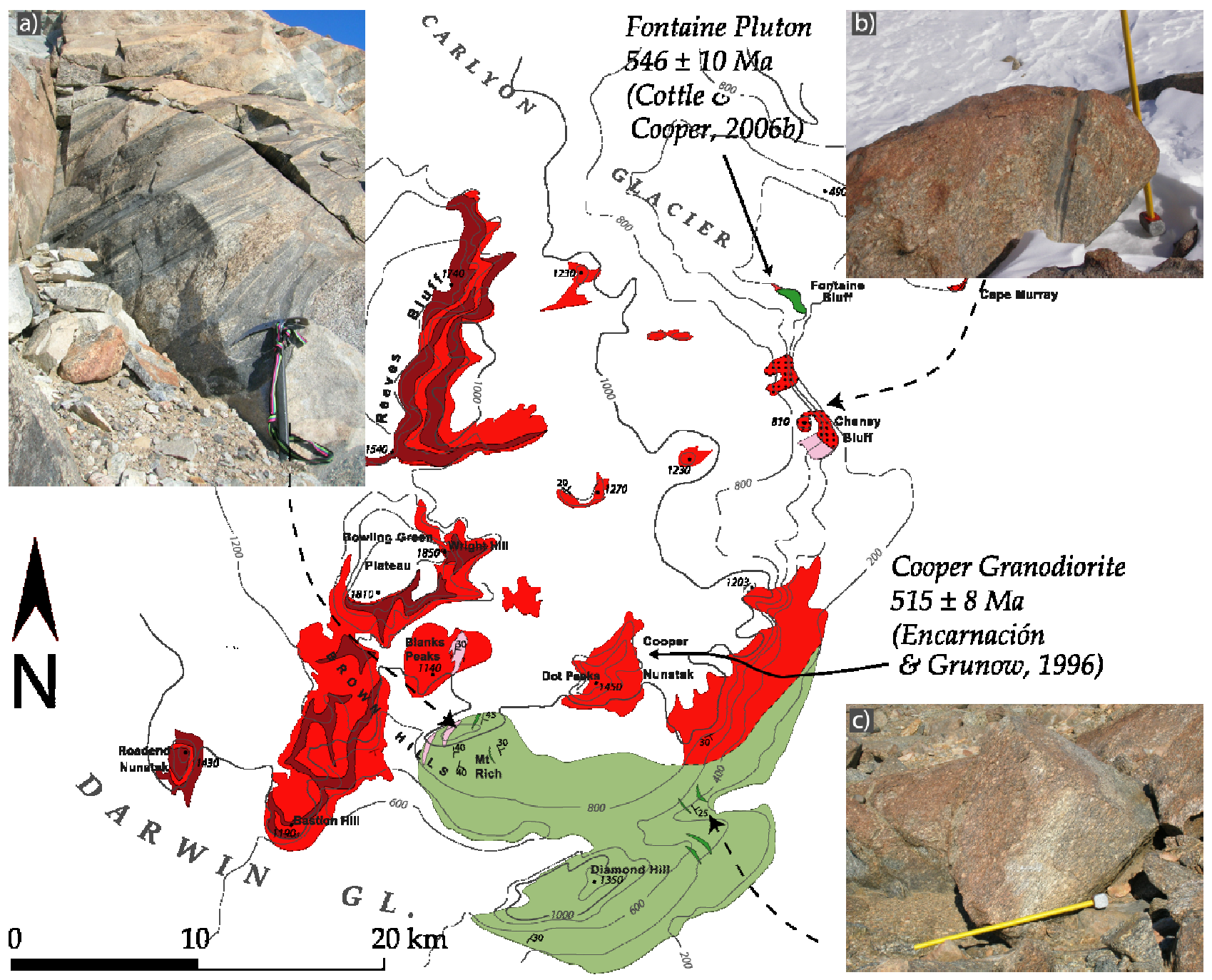

Figure 3. Geology on the north side of the Darwin Glacier: a) mylonitic fabrics within granodioritic orthogneisses; b) monzogranitic orthogneiss with relict rafts of host-paragneisses; c) granodioritic orthogneiss. See Figure 2 for the Legend.

the regional foliation of the gneisses. The deformation in the granitoids is heterogeneous and clearly developed during and after magma emplacement: igneous foliations in the porphyritic granitoids are locally well preserved (e.g. Mt. Rummage, Darnell Nunatak, Fig.2), but most of the intrusives bear evidence of postemplacement deformation and are transformed into orthogneisses with proto-mylonitic to mylonitic structures (eg. Bucknell Ridge, Mt. Rich, Fig. 3,4). Undeformed plutons, related to late- to post-kinematic igneous activity mainly consist of fine- to mediumgrained granites or two-mica leucogranites. Published geochronological data confirm the occurrence of two main groups of granitoids: the pre-to syn-kinematic with ages spanning from about 550 to $530 \mathrm{Ma}$ and the late- to post-kinematic granites with ages between 515 and 490 Ma. (Encarnación and Grunow 1996; Stump et al. 2006; Cottle and Cooper 2006a,b; Cottle, personal communication). Mafic-ultramafic rocks form small isolated bodies throughout the region comprised between the Byrd and Darwin Glaciers. Fresh hornblendite to melagabbro cumulates crop out in the central part of the Bucknell Ridge (northern side of the Darwin Glacier, Fig. 4) within a composite para- and orthogneiss sequence. Similar rocks are found also in isolated meter-scale blobs within the granitoids (Ramseyer Glacier) and as enclaves within the large gabbro-dioritic Fontaine Pluton, cropping out some 30 $\mathrm{km}$ north of the Darwin Glacier and interpreted by Cottle and Cooper (2006a) as a calc-alkaline gabbrodioritic body (zircon $\mathrm{U} / \mathrm{Pb}$ upper discordia intercept age at: $546 \pm 10 \mathrm{Ma})$.

\section{Structure and evolution $S$ of the Byrd Glacier}

Fold axes in the Byrd Group from the central Churchill Mountains (southern side of the Byrd 
Glacier) to the Nimrod Glacier area (about $300 \mathrm{~km}$ south of the Byrd glacier) follow general N-S trends. In the northern Churchill Mountains N-S and E-W orientations are common in places, whereas in the area immediately south of Byrd Glacier fold axes trend ENE sub-parallel to the glacier (Grindley and Laird, 1969).

Although only one generation of folding was generally recognized in the Shackleton Limestone, the fact that folded Shackleton Limestone is overlain unconformably by deformed Douglas Conglomerate in the Holyoke Range demonstrates that Shackleton Limestone was deformed at least twice in at least some localities (Rowell et al., 1988).

Skinner's (1965) map of the Mt. Madison massif shows fold trends ENE-WSW, NNW-SSE, and NW-SE at various places on the massif. According to Stump (1980) the S1 foliation is represented by a biotitebearing discontinuous layering. F1 fold closures with tight to isoclinal profiles are observed, suggesting a transposition of the original bedding. The $\mathrm{S} 1$ foliation is overprinted by a crenulation cleavage (S2), associated with mesoscopic folding. Schist and marble are spectacularly refolded in a complex F1 and F2 fold interference pattern on Contortion Spur resulting in a Type 3 pattern (classification according to Ramsay, 1967). The core of a synform, composed of grey- lightblue marble, has been tightly folded at the mesoscale, and plunges shallowly to the northeast. Thin (metrescale) layers of marble in schist and schist in marble can be traced throughout the outcrop, as well as the thicker (tens of meters) layers. The continuity of the individual layers of schist and marble at Contortion Spur represents the transposed bedding in a sequence of interbedded mudrocks and limestones. Both S0 and S1 strike ENE and dip steeply.

F1 fold axes trend mainly nearly parallel to L1 elongation lineation. This pattern is characteristic of sheath folds (Cobbold and Quinquis, 1980) and implies

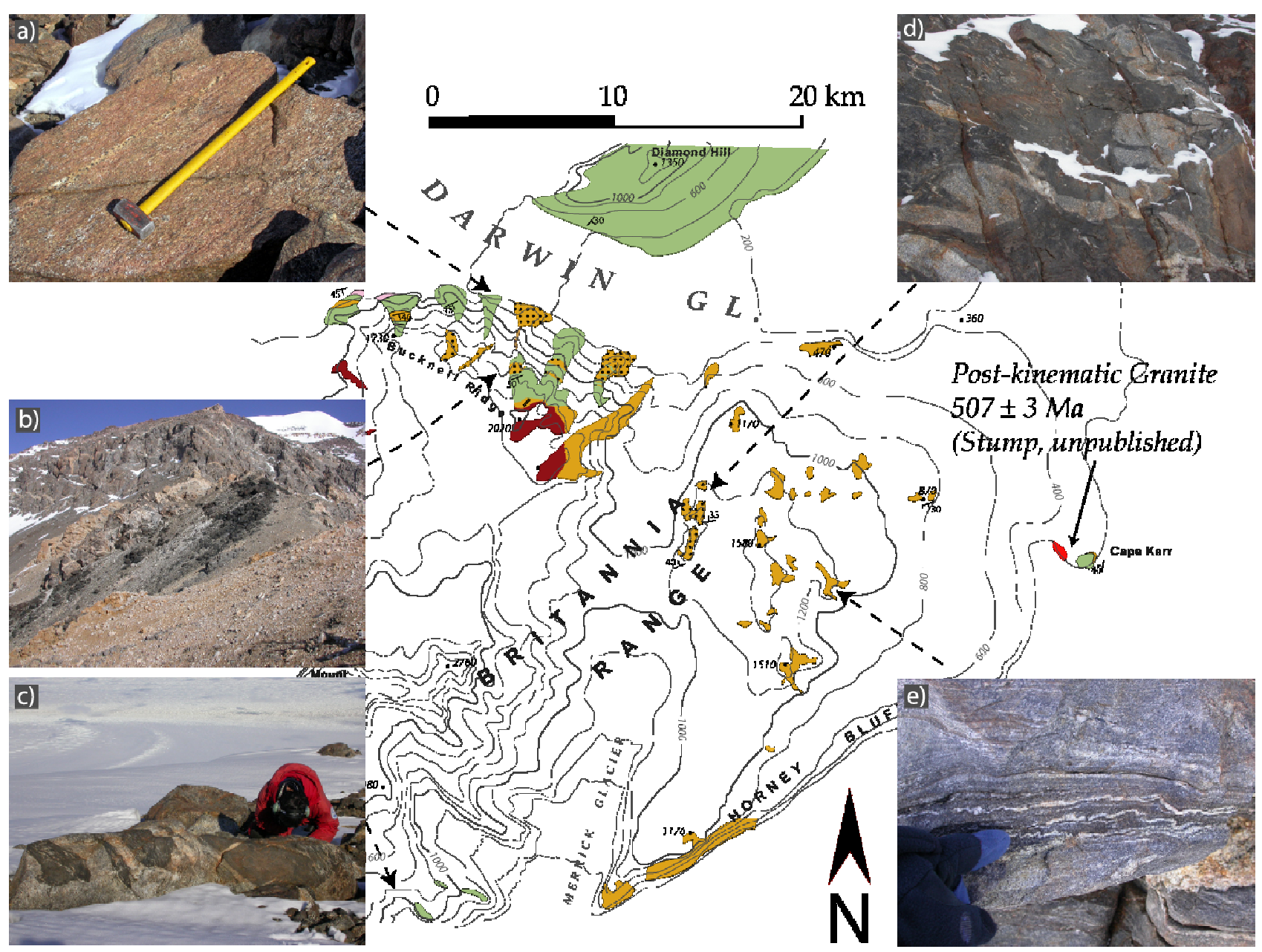

Figure 4. Geological map of the eastern Britannia Range and photographs of mesoscale outcrops. a) deformed granodiorite from Bucknell Ridge; b) cumulate gabbro body (150 meter long) within dominant deformed granodiorites at Bucknell Ridge; c) rafts of migmatitic gneisses within deformed granodiorites on the N-side of Merrick glacier; d) deformed granitic dykes within medium grade, Bt-Amp-bearing paragneisses; e) deformed BtAmp-bearing paragneisses with millimeter-scale leuocosomes. See Figure 2 for the Legend. 
shearing in the plane of foliation in the Mt. Madison area during D1 deformation. The S2 crenulation cleavage generally strikes NE-SW and the hinges of crenulations plunge shallowly.

\section{Structure and evolution north of the Byrd Glacier}

D1 deformation phase north of the Byrd Glacier is characterized by the development of a pervasive foliation in the orthogneisses and in the paragneisses. The deformation is heterogeneous and often localized within discrete shear zones (with development of mylonites) and in the less competent lithologies (pelitic paragneisses and calc-silicates). South of the De Vries Glacier and at Horney Bluff the most pelitic lithologies show tight isoclinal folds developing a feeble axial plane foliation. S1 foliation trends NNE-SSW to NESW moderately to steeply dipping to the WNW and NW respectively. F2 fold axes trend nearly E-W and mainly plunge to the west. Meter-scale shear zones are frequent and strike from nearly NNE-SSW to nearly E-W, with a WNW and north dip respectively. Locally they display an oblique elongation lineation. Stretching lineations in the mylonites, asymmetric F2 folds and the overall pattern of shortening and stretching direction of granitic dykes point to a top to the NE and SE shearing after the D1 deformation episode.

At Darnell Ntk. and Mt. Rummage (upper Byrd) the porphyritic granodiorites and monzogranites intrude concordantly the migmatitic paragneisses and show a well-developed igneous foliation characterized by statistical alignment of porphyritic K-Feldspar. Foliation in the paragneisses is concordant and strikes NE-SW (plunge to the NW) with a stretching lineation trending WNW-ESE.

In the Brown Hills (north side of the Darwin Gl.) a shear zone, several hundreds of meters thick, transposes a complex sequence of ortho- and paragneisses. Trails of less deformed hornblende-bearing gabbrosgabbrodiorites and rare melagabbro locally occur within the mylonitic sequence. The mafic boudins preserve igneous textures with euhedral hornblende, euhedral to subhedral plagioclase and poikilitic biotite. Field relationships clearly point to intrusion of mafic melts during the early stages of development of the shear zone. Subconcordant (and slightly deformed) to discordant (undeformed) aplitic dykes intrude the whole sequence. The dominant foliation in the entire area, comprising Mt. Rich and the Diamond Hills, dips to the east or ESE. Oblique stretching lineations and kinematic indicators like en-echelon boudins and asymmetric porphyroclasts suggest a top to the NE sense of shear.

\section{Tectono-metamorphic evolution of the Byrd Glacier area}

Based on new field data and recent published contributions a new geological map of the Britannia Range area has been produced: this integrates and refines the published maps that covered only partially in the area of interest (Haskell et al. 1964; Grindley and Laird 1969; Encarnación and Grunow 1996; Simpson and Cooper 2002).

A complex sequence of deformation and intrusions has been highlighted. Metamorphic rocks are dominated by strongly deformed $\mathrm{Bt} \pm \mathrm{Grt}$ and $\mathrm{Hbl}$ gneisses, often characterized by the occurrence of Hbl-bearing leucosomes and migmatitic textures. Sequences of finegrained pelitic schists or two-mica gneisses, interlayered with rare amphibolites and calcsilicate-fels locally occur. The metamorphic sequence is intruded, mostly concordantly by large amounts of pre- to syn-kinematic granodioritic to monzogranitic magma. Deformation in the granitoids is strongly heterogeneous and rare preserved igneous foliations are often overprinted by almost mylonitic gneissic textures. Undeformed granites are limited to few outcrops in the Britannia Range but their occurrence increases towards the north. Accordingly, recent published data (Stump et al. 2004, Cottle and Cooper, 2006a,b) point to the occurrence of old (550-530 Ma) and young (510-490 Ma) magmatic products. This confirms that even in this region two main magmatic pulses may be envisaged, like recently proposed for South Victoria Land (Allibone et al. 1993a,b; Encarnaciòn and Grunow 1996; Goodge and Fanning, 1999; Allibone and Wysoczansky 2002).

It is worth noting that the oldest plutonic pulses (545 $\pm 7 \mathrm{Ma}$ and $531 \pm 8$ : Stump et al. 2006) north of the Byrd Glacier occurred at the same time as deposition of Shackleton Limestone and lower Starshot Formation (Botomian), now located $\sim 40 \mathrm{~km}$ to the south on the southern side of the Byrd Glacier. Plutonic rocks of this age are also recognized further north in Darwin Glacier area (Cottle and Cooper 2006a,b). In contrast, Late Cambrian- Early Ordovician magmatism occurs on both sides of Byrd Glacier (Stump et al. 2006). The related undeformed magmatic rocks crosscut the regional structures. This implies that the Byrd Glacier discontinuity represents a crustal-scale structure whose activity most likely ceased before the onset of the lateRoss igneous activity. This tectonic event is responsible for a severe relative uplift of the northern sector with respect to the southern one, if we consider that oldest (550-530 Ma) plutonism north of Byrd Glacier is coeval with (or predates) the platform carbonate deposition to the south of Byrd Glacier. The new field survey further highlights the occurrence of a first-order orogenperpendicular structure developed for nearly one hundred kilometres across the general NNW-SSE trend of the Ross Orogen.

Acknowledgments. The authors thank the Programma Nazionale di Ricerche in Antartide (PNRA, Italy) for logistic support during austral seasons 2003/04 and 2005/06 and for funding Research Project 2002/4.2. J. McClintock, H. Kunzi, C. Nelson, R. Park, S. Spooner, S. Robertson (Helicopters New Zealand) and G. Ippolito (Scuola Militare Alpina, field assistant) are warmly acknowledged for the logistic support during the field work in the Britannia Range. Thanks 
are due to reviewers John Cottle and Anne Grunow and to lead and co-editors Alan Cooper and John Gamble for their constructive reviews on the early version of this manuscript. Digital drawing of the geological map by D. Nannini - Laboratorio di Cartografia Informatica DST Pisa.

\section{References}

Allibone, A.H., and R. Wysoczanski (2002), Initiation of magmatism during the Cambrian-Ordovician Ross orogeny in southern Victoria Land, Antarctica: Geological Society of America Bulletin, v. 114, no. 8, p. 1007-1018.

Allibone, A.H., S.C. Cox, and R.W. Smillie (1993a), Granitoids of the Dry Valleys area, southern Victoria Land: geochemistry and evolution along the early Paleozoic Antarctic craton margin: New Zealand Journal of Geology and Geophysics, v. v. 36, p. p. 281-297.

Allibone, A.H., S.C. Cox, I.J. Graham, R.W. Smillie, R. D. Johnstone, S. G. Ellery, and K. Palmer (1993b), Granitoids of the Dry Valleys area, southern Victoria Land, Antarctica; plutons, field relationships, and isotopic dating: New Zealand Journal of Geology and Geophysics, v. 36, no. 3, p. 281-297.

Borg, S.G., D.J. DePaolo, E.D. Wendlandt, and T. G. Drake (1989), Studies of granites and metamorphic rocks, Byrd Glacier area: Antarctic Journal of the United States, v. 24, no. 5, p. 19-21.

Cobbold, P.R., and H. Quinquis, (1980), Development of sheath folds in shear regimes: Journal of Structural Geology, v. 2, p. 119-126.

Cottle, J.M, and A.F. Cooper (2006a), The Fontaine Pluton: an early Ross Orogeny calc-alkaline gabbro from southern Victoria Land, Antarctica. New Zealand Journal of Geology \& Geophysics, 2006, 49: 177-189.

Cottle, J.M, and A.F. Cooper (2006b), Geology, geochemistry, and geochronology of an A-type granite in the Mulock Glacier area, southern Victoria Land, Antarctica. New Zealand Journal of Geology \& Geophysics, 49: 191-202.

Dalziel, I.W.D. (1997), Neoproterozoic-Paleozoic geography and tectonics: Review, hypothesis, environmental speculation: Geological Society of America Bulletin, v. 109, no. 1, p. 16-42.

Encarnación, J. P., and A.M. Grunow (1996), Changing magmatic and tectonic styles along the paleo-Pacific margin of Gondwana and the onset of early Paleozoic magmatism in Antarctica: Tectonics, v. 15, no. 6, p. 1325-1341.

Felder, R.P., and G. Faure (1990), Age and petrogenesis of the granitic basement rocks, Brown Hills, Transantarctic Mountains: Zentralblatt fur Geologie und Palaontologie, v. 1, p. 45-62.

Goodge, J.W., and C.M. Fanning (1999), 2.5 b.y. of punctuated Earth history as recorded in a single rock: Geology (Boulder), v. 27, no. 11, p. 1007-1010.

Goodge, J.W. (2002), From Rodinia to Gondwana: supercontinent evolution in the Transantarctic Mountains: Antarctica at the close of a millennium, edited by Gamble, J. A., Skinner, D. B. N., and S., Henrys, 61-74, Royal Society of New Zealand Bulletin 35, Wellington.

Grindley, G.W. (1963), The geology of the Queen Alexandra range, Beardmore glacier, Ross Dependency, Antarctica; with notes on the correlation of Gondwana sequences: New Zealand Journal of Geology and Geophysics, v. 6, no. 3, p. 307-347.

Grindley, G.W., and M.G. Laird (1969), Geology of the Shackleton Coast: Antarctic Map Folio Series, v. Folio 12, XIV.

Gunn, G.M., and G. Warren (1962), Geology of Victoria Land between Mawson and Mullock Glaciers, Antarctica. New Zealand Journal of the Geological Survey Bulletin 71, 157.

Haskell, T.R., J.P. Kennett, and W.M. Prebble (1964), Geology of the Brown Hills and Darwin Montains, Southern Victoria Land, Antarctica. Transactions of the Royal Society of New Zealand, 15, 2, 231-247.

Hoffman, P.F. (1991), Did Laurentia turn Gondwanaland inside-out?: Science, v. 252, p. 1409-1412.

Moores, E.M. (1991), Southwest U.S.-East Antarctic (SWEAT) connection; a hypothesis: Geology, v. 19, no. 5, p. 425-428.

Ramsay, J.G. (1967), Folding and fracturing of rocks: McGraw-Hill Book Company, New York, 560p.

Rowell, A. J., M.N. Rees, R.A. Cooper, and B.R. Pratt (1988), Early Paleozoic history of the central Transantarctic Mountains; evidence from the Holyoake Range, Antarctica: New Zealand Journal of Geology and Geophysics, v. 31, no. 4, p. 397-404

Skinner, D.N.B (1964), A summary of the geology between Byrd and Starshot Glaciers, south Victoria Land: Antarctic Geology, 284-292 edited by Adie, R. J., North-Holland, Amsterdam.

Skinner, D.N.B. (1965), Petrographic criteria of the rock units between the Byrd and Starshot Glaciers, South Victoria Land, Antarctica

Simpson, A.L., and A.F. Cooper (2002), Geochemistry of the Darwin Glacier region granitoids, southern Victoria Land. Antarctic Science Short Note, 14, 4, 425-426.

Stump, E. (1980), Two episodes of deformation at Mt. Madison, Antarctica: Antarctic Journal of the United States, v. 15, no. 5, 1980 review, p. 13-14.

Stump, E., K.A. Foland, W.R. Van Schmus, P.K. Brand, T.J. Dewane, B.F. Gootee and F. Talarico (2002), Geochronology of deformation, intrusion and cooling during the Ross orogeny, Byrd Glacier area, Antarctica. Geological Society of America Abstracts with Programs 34: 560-561.

Stump, E., B.F. Gootee, F. Talarico, W.R. van Schmus, P.K. Brand, K.A. Foland and C.M. Fanning (2004), Correlation of Byrd and Selborne Groups, with implications for the Byrd Glacier discontinuity, central Transantarctic Mountains, Antarctica. New Zealand Journal of Geology \& Geophysics, Vol. 47: 157-171.

Stump, E., B.F. Gootee, and F. Talarico (2006), Tectonic Model for Development of the Byrd Glacier Discontinuity and Surrounding Regions of the Transantarctic Mountains during the Neoproterozoic - Early Paleozoic: Antarctica - Contributions to Global Earth Sciences, 181-190 edited by Fütterer, D.K., D. Damaske, G, Kleinschmidt, H. Miller, and F. Tessensohn, Springer Berlin Heidelberg. 